\title{
Use of Differential Scanning Calorimetry and Immunoaffinity Chromatography to Identify Disease Induced Changes in Human Blood Plasma Proteome
}

\author{
Sandi Brudar, ${ }^{1}$ Urh Černigoj, ${ }^{2}$ Helena Podgornik, ${ }^{3}$ Mojca Kržan ${ }^{4}$ \\ and Iztok Prislan ${ }^{5 *}$ \\ ${ }^{1}$ University of Ljubljana, Faculty of Chemistry and Chemical Technology, 1000 Ljubljana, Slovenia \\ ${ }^{2}$ BIA Separations, 5270 Ajdovščina, Slovenia \\ ${ }^{3}$ University Medical Centre Ljubljana, Department of Haematology, 1000 Ljubljana, Slovenia \\ ${ }^{4}$ University of Ljubljana, Faculty of Medicine, 1000 Ljubljana, Slovenia \\ ${ }^{5}$ University of Ljubljana, Biotechnical Faculty, 1000 Ljubljana, Slovenia \\ * Corresponding author: E-mail: iztok.prislan@bf.uni-lj.si
}

Received: 05-10-2016

For Cutting Edge 2017

\begin{abstract}
Differential scanning calorimetry provides unique signatures of blood plasma samples. Plasma samples from diseased individuals yield specific thermograms, which differ from each other and from plasma samples of healthy individuals. Thermograms from individuals suffering from chronic lymphocytic leukemia, multiple myeloma and acute myeloid leukemia were measured with DSC. To obtain additional information about thermal behaviour of plasma proteins immunoaffinity chromatography was introduced. An immunoextraction of HSA using a chromatographic column with immobilized anti-HSA was carried out in order to enrich less abundant plasma proteins, which could provide a further insight into disease development. Efficiency of HSA depletion and protein composition of fractionated plasma was validated by SDS-PAGE.
\end{abstract}

Keywords: DSC, IAC, blood plasma, immunoextraction, diagnostic tool

\section{Introduction}

Despite of rapid development of medicine and other sciences, timely and reliable diagnosis of diseases is sometimes still a pretentious task. In addition when it comes to ascertaining the health status of an individual some diagnostic procedures are very invasive. A solution to such difficulties could lie in new methods for human plasma analysis. Human plasma serves as an important source of information about human health. Various diseases are often associated with biomarkers, which have been defined by Hulka et al. as biochemical, molecular or cellular changes that are measureable in human fluids, tissues and cells. ${ }^{1}$ The human plasma proteome consists of more than
3000 proteins and peptides, therefore the search for potential disease biomarkers, and their identification in the plasma proteome is a very complicated procedure. ${ }^{2}$ Only ten proteins make up $90 \%$ of the mass of plasma proteins and albumin (HSA) and immunoglobulins (Ig) represent 75\% out of these ten proteins. Majority of biomarkers in blood plasma are often scarce and small in size. Consequently, their detection can be limited by the presence of more abundant and larger proteins such as $\mathrm{HSA}$ or $\mathrm{IgG}^{2}$. Because of the complexity of plasma no single technique can fully exploit the information plasma has to offer. Until now mass spectrometry and 2D-electrophoresis have been routinely used for detection and characterization of specific biomarkers. ${ }^{3}$ Chaires et al. have discovered the poten- 
tial use of differential scanning calorimetry (DSC) for plasma analysis. ${ }^{2}$ Using a DSC to analyze plasma yields a thermogram that is sensitive to differences in thermodynamic properties of the most abundant plasma proteins. Chaires et al. have shown that thermograms of plasma from diseased individuals differ significantly from thermograms of plasma from healthy individuals. ${ }^{2,4}$ Another tool to facilitate the search for biomarkers is liquid chromatography, in particular affinity chromatography and ion-exchange chromatography. Several researchers have demonstrated that depletion of most abundant plasma proteins amplifies the contribution of least abundant plasma proteins, thus creating the opportunity to uncover and study specific proteins/peptides. ${ }^{5,6}$ Polymethacrylate chromatographic monoliths afford flow rate independent binding capacity and resolution for large biomolecules due to the convective nature of the flow, which allows relatively short analysis times compared to traditional chromatographic supports. ${ }^{7}$ Having these advantages in mind we decided to partially deplete human serum albumin from plasma sample using chromatographic monoliths bearing immunoaffinity ligand. The purpose of our research was to develop and optimize procedures for combined use of DSC and immunoaffinity chromatography (IAC) for the investigation of different plasma samples from diseased individuals.

\section{Experimental}

\section{1. Plasma Samples}

We investigated plasma samples from three individuals with three different haematological diseases, namely chronic lymphocytic leukemia (CLL), multiple myeloma (MM) and acute myeloid leukemia (AML). Individuals diagnosed with MM and AML were females and the one with CLL was a male. Due to ethical issues further information about these individuals cannot be revealed. Chaires et al. ${ }^{8}$ have shown that the main shape of plasma thermograms is unbiased by age, gender and ethnicity, however small deviations in HSA unfolding signal amplitudes can be observed due to higher HSA concentrations in male plasma samples. For the control sample blood plasma from a healthy child was used. At the University Medical Centre Ljubljana (UMCL) the peripheral blood samples were withdrawn in tubes with EDTA and centrifuged at 2500 RPM for 10 minutes to obtain plasma. The use of plasma was approved by National Medical Ethics Committee (Approval number: MZ 0120-299/2016-2, KME 83/05/16)

Because only 3 plasma samples were investigated we have to emphasize that this is only a preliminary study in which our main aim was to identify the effectiveness of our approach and not to generalize differences for the three investigated diseases. It should be clear that for validation of our method more plasma samples should be analyzed. Even though only one set of measurements was performed for CLL and AML samples, the robustness and reproducibility of our method was tested with other plasma samples (data not shown) and two separate fractionations of MM sample (Figure S1).

\section{2. Sample Preparation}

The buffer solutions used in our experiments consisted of $20 \mathrm{mM}$ disodium phosphate and $300 \mathrm{mM} \mathrm{NaCl}$. $\mathrm{HCl}$ was added to disodium phosphate to reach $\mathrm{pH}$ of 7.4. All buffers were filtered before use. Samples were first diluted 5- to 7-fold and then extensively dialyzed against the buffer at $4{ }^{\circ} \mathrm{C}$ (three changes of buffer solution in $24 \mathrm{~h}$ ) using a dialysis tube Float-A-Lyzer with a 3500 Da cut-off. Total protein concentration of plasma samples was determined spectrophotometrically according to the bicinchoninic acid method procedure (Sigma-Aldrich). ${ }^{9}$

\section{3. IAC Protocol}

Separations were performed using a Knauer highperformance liquid chromatography (HPLC) workstation, consisting of two pumps, an autosampler injection system with a sample loop volume of $100 \mu \mathrm{L}$ and a UVdetector at a wavelength of $280 \mathrm{~nm}$. Samples were loaded by using a mobile phase consisting of $20 \mathrm{mM}$ disodium phosphate and $300 \mathrm{mM} \mathrm{NaCl}, \mathrm{pH}=7.4$ at a flow rate of 1 $\mathrm{mL} / \mathrm{min}$. For experimental data acquisition, Eurochrom 2000 software was used. The hydrazide-modified monolithic chromatographic column (CIM ${ }^{\circledR}$ HIDA) with $1 \mathrm{~mL}$ bed volume and $6 \mu \mathrm{m}$ pore size was provided by BIA Separations d.o.o. The immobilization of polyclonal antiHSA was performed according to the procedure described by Tarasova et al. ${ }^{10}$ and the determined dynamic binding capacity at 50\% breakthrough of prepared CIM $\alpha$ HSA column for pure HSA in phosphate buffered saline was $0.35 \mathrm{mg} / \mathrm{mL}$. Before injection, diluted and dialyzed plasma samples were filtered through $0.45 \mu \mathrm{m}$ membrane filters (Sartorius) and diluted with dialysate to a total protein concentration of approximately 4 to $5 \mathrm{mg} / \mathrm{mL} .100 \mu \mathrm{l}$ loop was used to load the sample and flow-through and bound fractions of plasma were collected. Succeeding collection of flow-through fraction the bound fraction was eluted using $0.1 \mathrm{M} \mathrm{HCOOH}, \mathrm{pH}=2.5$, followed by immediate neutralization by $200 \mathrm{mM}$ disodium phosphate, $300 \mathrm{mM} \mathrm{NaCl}, \mathrm{pH}=8.5$. Both fractions were transferred to Vivaspin sample concentrators with MWCO of $3500 \mathrm{Da}$ and centrifuged to final volume of 1 to $1.5 \mathrm{~mL}$ at 5000 RPM. This was repeated 18 times.

\section{4. DSC Protocol}

DSC thermograms were obtained using nano DSC II (CSC). Dialyzed plasma samples were diluted 3- to 4-fold with dialysate and degassed for $15 \mathrm{~min}$. DSC scans were 
recorded from $20{ }^{\circ} \mathrm{C}$ to $100{ }^{\circ} \mathrm{C}$ at $2{ }^{\circ} \mathrm{C} / \mathrm{min}$. Corresponding buffer scans were also recorded. Raw data was analyzed with NanoAnalyze software and Microsoft Excel. The corresponding baseline (buffer-buffer) scans were subtracted from the plasma scans and normalized to total protein concentration to obtain partial heat capacity as a function of temperature.

\section{5. SDS-PAGE}

Fractions were examined using sodium dodecyl sulfate polyacrylamide gel electrophoresis (SDS-PAGE). Plasma fractions from IAC were diluted to a final concentration between 0.5 and $1.0 \mathrm{mg} / \mathrm{mL}$. Separation of proteins was performed on $12 \%$ resolving gel and $4 \%$ stacking gel. Electrophoresis was carried out under reducing conditions according to the basic Laemmli SDS-PAGE procedure. ${ }^{11}$ Gels were run at $200 \mathrm{~V}$ and $15{ }^{\circ} \mathrm{C}$ for $75 \mathrm{~min}$. Visualization of protein bands was done by silver staining. ${ }^{12} \mathrm{Gel}$ images were altered to achieve more efficient interpretation of result (color was changed to black\&white and positions of lanes on the same gel were shuffled). Unaltered images can be seen in Figure S2.

\section{Results and Discussion}

\section{1. Comparison of Blood Plasma Thermograms}

Figure 1 shows that plasma thermograms belonging to diseased individuals differ significantly from one another and from "healthy" plasma thermograms. The thermo-

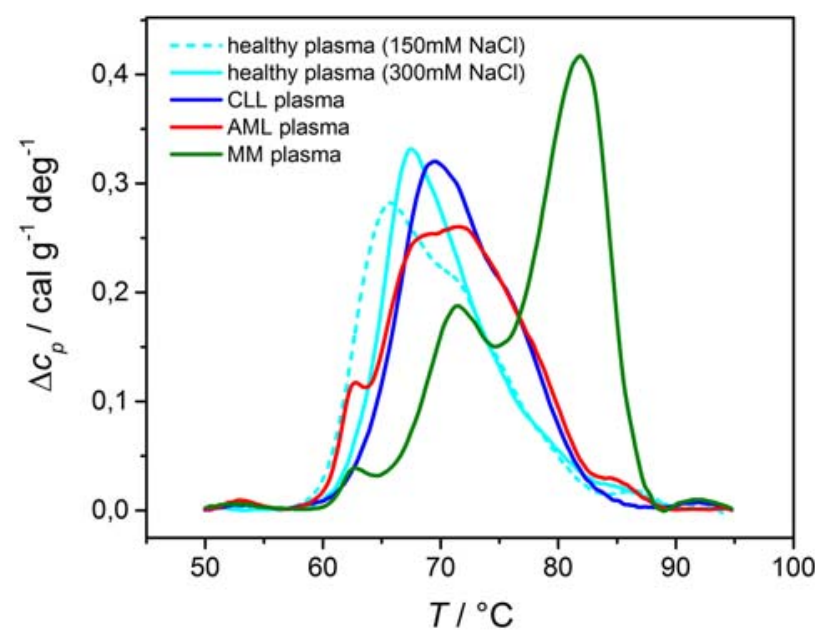

Figure 1. Comparison of thermograms of blood plasma from diseased individuals dissolved in $20 \mathrm{mM}$ phosphate buffer and $300 \mathrm{mM}$ $\mathrm{NaCl}$ and with a thermogram of blood plasma from healthy individual dissolved in $10 \mathrm{mM}$ phosphate buffer and $150 \mathrm{mM} \mathrm{NaCl}$ (dashed cyan line) and $20 \mathrm{mM}$ phosphate buffer and $300 \mathrm{mM} \mathrm{NaCl}$ (full cyan line). grams of plasma display multiple peaks that can be associated to the melting temperatures $\left(T_{\mathrm{m}}\right)$ characteristic of main plasma proteins.

Chaires et al. have performed thermal denaturation of "healthy" blood plasma at heating rate of $1{ }^{\circ} \mathrm{C} / \mathrm{min}$ and in $10 \mathrm{mM}$ phosphate buffer with $150 \mathrm{mM} \mathrm{NaCl}$ to mimic physiological conditions. Several peaks were identified corresponding to transition temperatures of fibrinogen $\left(T_{\mathrm{m}} \sim 51{ }^{\circ} \mathrm{C}\right), \mathrm{HSA}\left(T_{\mathrm{m}} \sim 63{ }^{\circ} \mathrm{C}\right), \operatorname{IgG}\left(T_{\mathrm{m}} \sim 70{ }^{\circ} \mathrm{C}\right)$ and transferrin $\left(T_{\mathrm{m}} \sim 85^{\circ} \mathrm{C}\right){ }^{2}$ Thermograms in our research were recorded at heating rate of $2{ }^{\circ} \mathrm{C} / \mathrm{min}$ to increase the number of processed samples and $20 \mathrm{mM}$ phosphate buffer with $300 \mathrm{mM} \mathrm{NaCl}$ was used to avoid non-specific plasma-column interactions. Higher heating rate and salt concentration shifted the melting temperatures of majority of plasma proteins to higher values (Figure 1). Thus $T_{\mathrm{m}}$ of fibrinogen shifts to $\sim 53{ }^{\circ} \mathrm{C}, T_{\mathrm{m}}$ of HSA to $\sim 67{ }^{\circ} \mathrm{C}$, $T_{\mathrm{m}}$ of IgG to $\sim 72{ }^{\circ} \mathrm{C}$ ) and $T_{\mathrm{m}}$ of transferrin to $\sim 86{ }^{\circ} \mathrm{C}$. Melting temperatures are not the only obtainable data from thermograms. The integration of area under the thermograms of plasma yields the enthalpy of plasma proteins denaturation (Table 1).

Table 1. Denaturation enthalpies of plasma from healthy individual and from blood plasma of diseased individuals. NF-non-fractionated plasma; F1-flow-through plasma fraction. Experimental error due to baseline correction is $\pm 5 \%$. $^{13}$

\begin{tabular}{cc}
\hline Sample & Unfolding enthalpy [cal/g] \\
\hline Healthy plasma & $3.64 \pm 0.18$ \\
CLL plasma NF & $3.80 \pm 0.19$ \\
CLL plasma F1 & $2.94 \pm 0.15$ \\
AML plasma NF & $3.96 \pm 0.20$ \\
AML plasma F1 & $2.89 \pm 0.14$ \\
MM plasma NF & $4.57 \pm 0.23$ \\
MM plasma F1 & $4.27 \pm 0.21$ \\
\hline
\end{tabular}

Figure 1 shows that thermograms obtained from thermal denaturation of blood plasma from diseased individuals are shifted to higher temperatures. The shift in unfolding temperatures is in agreement with previously reported results for other diseases. ${ }^{2,14,15,16}$ Proteins in plasma from diseased individuals seem to unfold at higher temperatures for a yet undefined reason. Chaires et al. had hypothesized that such stabilization of proteins occurs due to interactions between major plasma proteins and specific disease biomarkers. ${ }^{2}$ Thermal denaturation of plasma from an individual with CLL yields a thermogram, where at least four transitions could be identified. These could correspond to denaturation of fibrinogen $\left(T_{\mathrm{m}} \sim 53{ }^{\circ} \mathrm{C}\right)$, HSA $\left(T_{\mathrm{m}} \sim 68{ }^{\circ} \mathrm{C}\right), \operatorname{IgG}\left(T_{\mathrm{m}} \sim 72{ }^{\circ} \mathrm{C}\right)$ and transferrin $\left(T_{\mathrm{m}} \sim 91\right.$ $\left.{ }^{\circ} \mathrm{C}\right)$. The transitions are shifted from 0 to $5{ }^{\circ} \mathrm{C}$ towards higher temperatures when compared to thermogram of "healthy" plasma. For instance, $T_{\mathrm{m}}$ of fibrinogen does not change, but $T_{\mathrm{m}}$ of transferrin is shifted for approximately 
$5{ }^{\circ} \mathrm{C}$. The denaturation enthalpy of non-fractionated CLL plasma is $3.80 \pm 0.19 \mathrm{cal} / \mathrm{g}$. This value is approximately the same as the denaturation enthalpy of plasma proteins from healthy individuals. Figure 1 shows that DSC thermograms of CLL and AML plasma are distinct even though both diseases are characterized by prominent changes in blood leukocytes not in plasma protein composition. In the thermogram of plasma from an individual with AML an additional endothermic peak can be observed at $62{ }^{\circ} \mathrm{C}$. We hypothesize this peak is present due to thermal denaturation of haptoglobin, as it is supposed to unfold in the same temperature region as $\mathrm{HSA}^{2}{ }^{2} T_{\mathrm{m}}$ values of fibrinogen and transferrin from AML plasma denaturation seem to be at approximately the same position as $T_{\mathrm{m}}$ values from "healthy" plasma denaturation. The denaturation enthalpy of non-fractionated blood plasma from an individual with AML is $3.96 \pm 0.20 \mathrm{cal} / \mathrm{g}$, which is comparable to denaturation enthalpy of CLL and "healthy" plasma. Lastly Figure 1 shows a specific thermogram of plasma from an individual with MM. Three main transition peaks for most abundant plasma proteins can be characterized. A similar thermogram for this disease was obtained by Todinova et al. ${ }^{17}$ Thermally induced peaks are shifted to higher temperatures to an even greater extent than those characteristic for proteins from CLL and AML plasma samples. Also in contrast to AML and CLL samples protein concentration in MM plasma was increased above reference range $(94 \mathrm{~g} / \mathrm{L})$ due to monoclonal $\mathrm{IgG}$ fraction (M spike) typical for MM. Thermogram exhibits three distinct peaks $\left(T_{\mathrm{m} 1} \sim 62{ }^{\circ} \mathrm{C}, T_{\mathrm{m} 2} \sim 71{ }^{\circ} \mathrm{C}\right.$ and $T_{\mathrm{m} 3} \sim 82$ ${ }^{\circ} \mathrm{C}$ ) and is dramatically different from other thermograms. The determined enthalpy of denaturation for non-fractionated MM plasma was $4.57 \pm 0.23 \mathrm{cal} / \mathrm{g}$, which is approximately $20 \%$ higher from denaturation enthalpies of other samples. These results suggest that the amount of unfolding enthalpy is not a determining factor for disease conditions. We believe that only the shape of plasma thermograms can serve as a diagnostic tool for disease determination.

\section{2. Fractionation and Characterization of Proteins in Blood Plasma}

To gain further insight into thermal behavior of different blood plasma samples, fractionation of plasma samples and thermal denaturation of obtained fractions were carried out. The thermogram of the flow-through fraction of plasma from an individual with CLL in Figure 2 shows a distinct drop in signal intensity in the region characteristic of HSA, as a result of HSA depletion by a CIM $\alpha$ HSA column. As a result, transition peaks for other proteins are more pronounced. Along with enrichment of less abundant proteins we can observe an entirely new peak at approximately $65^{\circ} \mathrm{C}$, which seems to have been previously masked by HSA. We hypothesize that this peak is a result of haptoglobin denaturation.
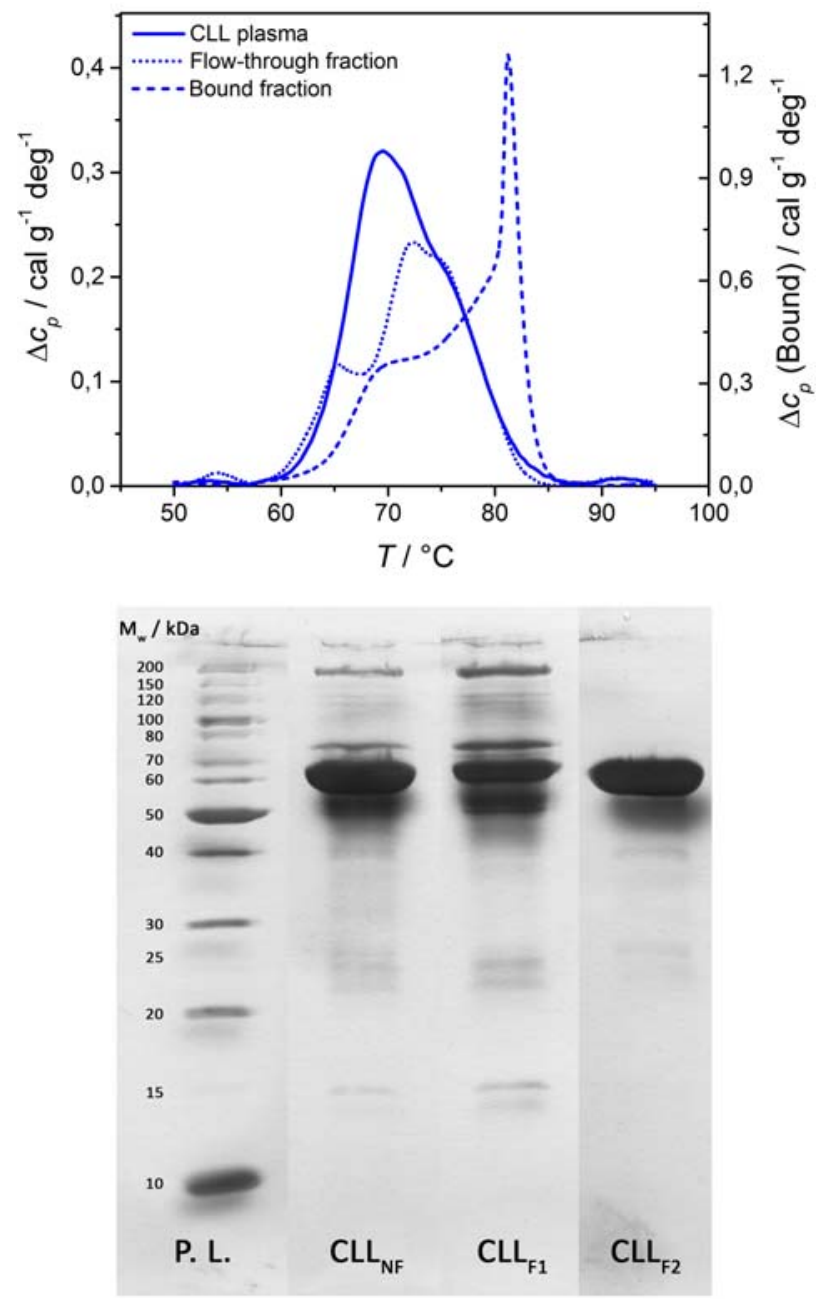

Figure 2. Thermograms of blood plasma from an individual with CLL (top). DSC thermogram of a non-fractionated blood plasma sample (full line) is compared to thermograms of flow-through (dotted line) and bound fraction (dashed line) obtained from HPLC fractionation. The right $\Delta \mathrm{C}_{p}$ axis corresponds to the bound fraction. SDS-PAGE of blood plasma from an individual with CLL (bottom); P. L. - protein library, $\mathrm{CLL}_{\mathrm{NF}}-$ non-fractionated blood plasma $(1 \mathrm{mg} / \mathrm{mL}), \mathrm{CLL}_{\mathrm{F} 1}$ - flow-through fraction $(1 \mathrm{mg} / \mathrm{mL}), \mathrm{CLL}_{\mathrm{F} 2}$ - bound fraction $(0.8 \mathrm{mg} / \mathrm{mL})$.

The obtained unfolding enthalpy of the flowthrough fraction of CLL plasma was $2.94 \pm 0.15 \mathrm{cal} / \mathrm{g}$ (Table 1), which is $22 \%$ lower than that of non-fractionated plasma. The thermogram of the bound fraction in Figure 2 shows a major exothermic effect above $82{ }^{\circ} \mathrm{C}$ due to protein aggregation. We hypothesize that this phenomenon is due to elution of HSA with $\mathrm{HCOOH}$, even though this fraction was intercepted by high capacity buffer to neutralize acid. Very acidic conditions are nonphysiological for HSA and can change its structure in a way that favors aggregation. Similar behavior of bound fractions was observed in all plasma samples and reported by other researchers ${ }^{18,19}$ and will not be discussed any further. Together with the thermogram of the flow- 
through fraction, results of SDS-PAGE (Figure 2) show that only partial HSA depletion was achieved even though the applied concentration was bellow theoretical binding capacity. This was most likely due to complexity of plasma samples and overuse of our CIM $\alpha$ HSA column. Even though HSA is still present in the flowthrough fraction, the corresponding thermogram seems to be missing peak assigned to HSA denaturation. We have to assume that HSA unfolding is masked by the unfolding of other plasma proteins. $\mathrm{CLL}_{\mathrm{F} 2}$ lane (bound fraction) displays an intensive band at $66 \mathrm{kDa}$, characteristic of HSA, no slower migrating bands and some low intensity bands in lower MW region that could correspond to heavy $(\sim 50 \mathrm{kDa})$ and light $(\sim 25 \mathrm{kDa})$ IgG chains. Results of flow-through fraction PAGE can be seen in $\mathrm{CLL}_{\mathrm{F} 1}$ la-
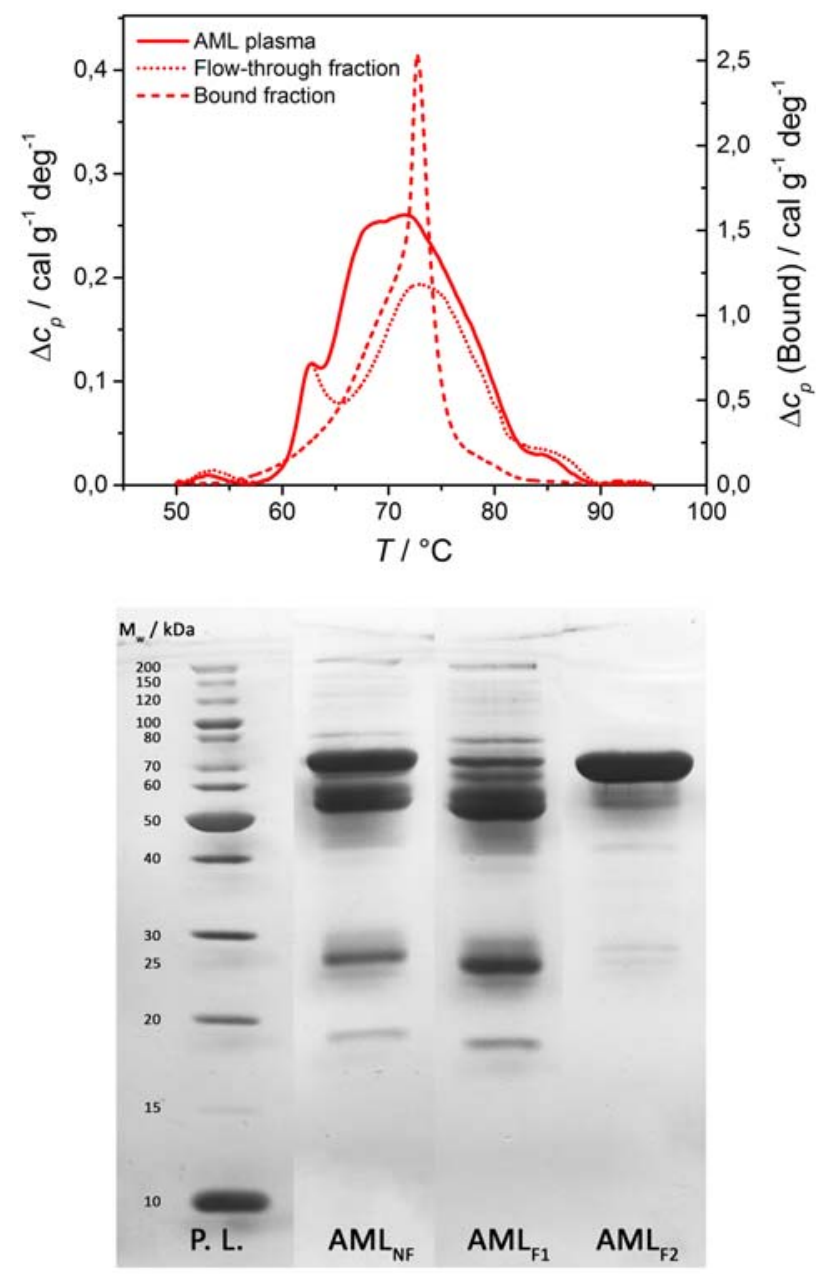

Figure 3. Thermograms of blood plasma from an individual with AML (top). DSC thermogram of a non-fractionated blood plasma sample (full line) is compared to thermograms of flow-through (dotted line) and bound fraction (dashed line) obtained from HPLC fractionation. The right $\Delta \mathrm{C}_{p}$ axis corresponds to the bound fraction. SDS-PAGE of blood plasma from an individual with AML (bottom); P. L. - protein library, $\mathrm{AML}_{\mathrm{NF}}-$ non-fractionated blood plasma $(1 \mathrm{mg} / \mathrm{mL}), \mathrm{AML}_{\mathrm{F} 1}$ - flow-through fraction $(1 \mathrm{mg} / \mathrm{mL}), \mathrm{AML}_{\mathrm{F} 2}$ - bound fraction $(0.7 \mathrm{mg} / \mathrm{mL})$. ne. An intensive band at $\sim 180 \mathrm{kDa}$, representing a subunit of $\alpha_{2}$-macroglobulin, is present in the high MW $\gamma$-region. Below in the $\beta$-region lies a distinct band at $80 \mathrm{kDa}$, characteristic of transferrin. HSA band is less intensive but still present because in order to reduce the number of fractionations, high concentration of plasma with HSA concentration on the limit of binding capacity was injected on CIM $\alpha$ HSA column. Beneath the band representing HSA there is a broader band consisting of $\mathrm{B} \beta$-fibrinogen at $\sim 56 \mathrm{kDa}$, transthyretin at $\sim 55 \mathrm{kDa}$ and heavy Ig$\mathrm{G}$ chains at $\sim 50 \mathrm{kDa}$. The band at $\sim 15 \mathrm{kDa}$ could not be identified..$^{20}$ It is clear that intensities of all bands, which were weaker in the whole plasma sample are noticeably increased in the $\mathrm{CLL}_{\mathrm{F} 1}$ lane, suggesting that enrichment of less abundant proteins was successful.
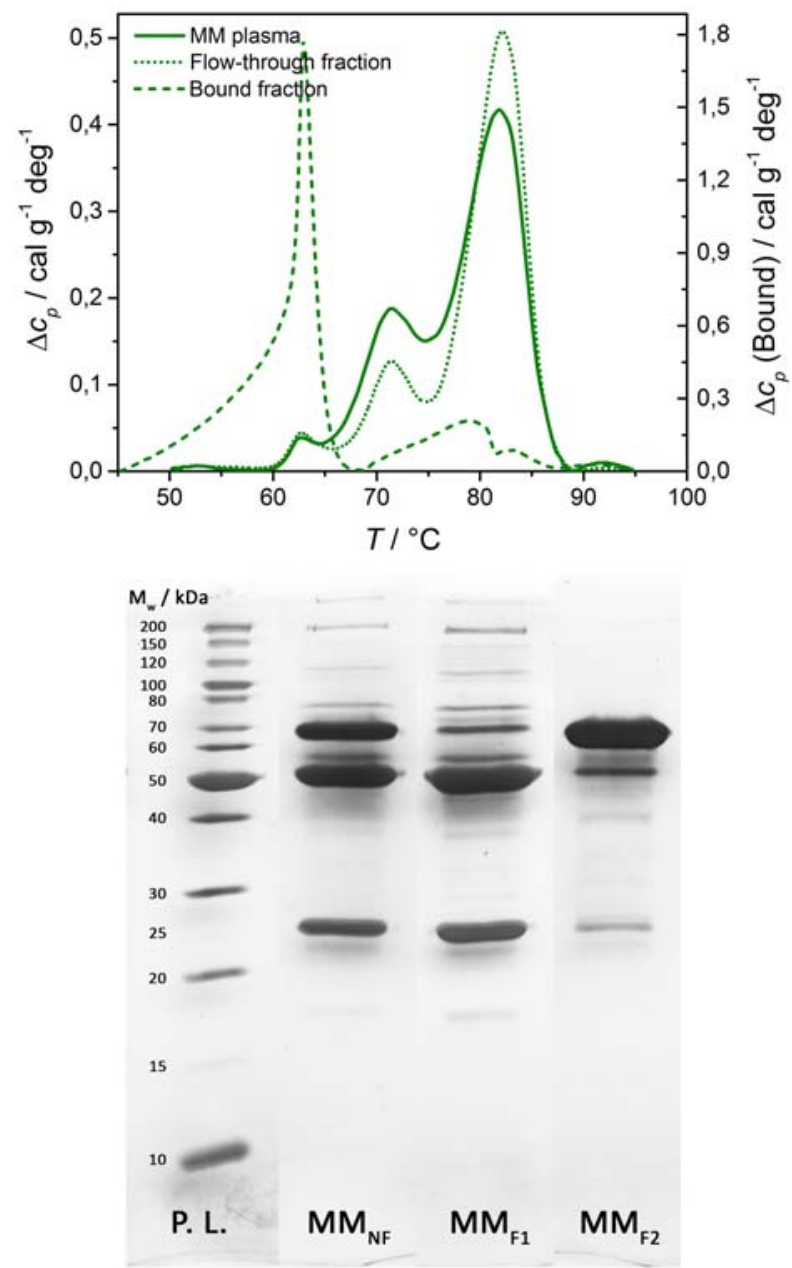

Figure 4. Thermograms of blood plasma from an individual with MM (top). DSC thermogram of a non-fractionated blood plasma sample (full line) is compared to thermograms of flow-through (dotted line) and bound fraction (dashed line) obtained from HPLC fractionation. The right $\Delta \mathrm{C}_{p}$ axis corresponds to the bound fraction. SDS-PAGE of blood plasma from an individual with MM (bottom); P. L. - protein library, $\mathrm{MM}_{\mathrm{NF}}-$ non-fractionated blood plasma $(1 \mathrm{mg} / \mathrm{mL}), \mathrm{MM}_{\mathrm{F} 1}$ - flow-through fraction $(1 \mathrm{mg} / \mathrm{mL}), \mathrm{MM}_{\mathrm{F} 2}-$ bound fraction $(0.5 \mathrm{mg} / \mathrm{mL})$. 
The thermogram of the flow-through fraction of AML plasma (Figure 3) shows that depletion of HSA from blood plasma resulted in well-defined peak at $62{ }^{\circ} \mathrm{C}$ which in our opinion is a result of haptoglobin denaturation. Signals for other plasma proteins, such as fibrinogen at $53{ }^{\circ} \mathrm{C}$ and transferrin at $86^{\circ} \mathrm{C}$ are also slightly enriched. The remaining peak at $72{ }^{\circ} \mathrm{C}$ can be attributed to IgG denaturation. The obtained unfolding enthalpy for the flowthrough fraction was $2.89 \pm 0.14 \mathrm{cal} / \mathrm{g}$ (Table 1), which is approximately $27 \%$ lower than for non-fractionated AML plasma. Thermogram obtained from thermal denaturation of the bound fraction of AML plasma (Figure 3) displays an intensive endothermic peak, followed by a steep exothermic effect characteristic of protein aggregation. Results of SDS-PAGE of AML plasma (Figure 3) show an intensive $\mathrm{HSA}$ band in $\mathrm{AML}_{\mathrm{F} 2}$ lane, suggesting that we have successfully depleted the majority of HSA from the AML plasma. Some faster migrating bands corresponding to heavy $(\sim 50 \mathrm{kDa})$ and light $(\sim 25 \mathrm{kDa}) \mathrm{IgG}$ chains can also be seen in $\mathrm{AML}_{\mathrm{F} 2}$ lane. $\mathrm{AML}_{\mathrm{F} 1}$ lane corresponds to the flow-through fraction and contains a band at $66 \mathrm{kDa}$ showing that not all of HSA was removed. The intensities of other bands are increased, proving that we have succeeded in increasing the relative concentration of other proteins.

When comparing thermograms of non-fractionated sample and flow-through fraction of the MM plasma (Figure 4), a distinct drop in signal intensity at temperature of $71^{\circ} \mathrm{C}$ and increase in signal intensity at temperature of $82{ }^{\circ} \mathrm{C}$ are observed. The denaturation enthalpy of the flow-through fraction was $4.27 \pm 0.21 \mathrm{cal} / \mathrm{g}$, which is only $7 \%$ lower than for non-fractionated MM plasma. SDSPAGE of MM flow-through fraction, $\mathrm{MM}_{\mathrm{F} 1}$, shows decreased intensity of HSA band at $66 \mathrm{kDa}$ and increased intensities of other bands (Figure 4). On the other hand SDS-PAGE of MM bound fraction, $\mathrm{MM}_{\mathrm{F} 2}$, shows strong band, characteristic of HSA along with weaker bands representing heavy and light IgG chains. SDS-PAGE results suggest that almost all of the HSA is removed from flow through fraction which could be associated to drop in DSC signal intensity at temperature of $71{ }^{\circ} \mathrm{C}$. Thermograms of MM plasma show that HSA and IgG unfolding have shifted to higher temperature, perhaps due to interactions with drug ${ }^{21}$ or interactions with monoclonal immunoglobulin. ${ }^{22}$ About $25 \%$ drop in DSC signal intensity at temperature of $71^{\circ} \mathrm{C}$ does not correspond to drop in band intensity observed in SDS-PAGE which means that HSA is unfolding in the same region as other proteins. Comparison of lanes with bound fractions in Figures 2, 3 and 4 reveals that the intensities faster migrating bands are strongest in the case of MM plasma. This could be a result of HSA-IgG complex formation, non-specific interactions or column degradation and should be further investigated. The stained gel (Figure 4) gives information not only about the effectiveness of MM plasma fractionation, but also of multiple myeloma signs. This is especially evident from several protein bands in $\mathrm{MM}_{\mathrm{NF}}$ lane. A weak band, characteristic of HSA and abnormally intensive bands, characteristic of heavy and light IgG chains can be observed. Both phenomena are typical of multiple myeloma ${ }^{20}$ and it should be emphasized that MM plasma was obtained from patient with $\operatorname{IgG}$ clonality and light chain kappa restriction.

\section{Conclusions}

DSC provides a unique signature of the three examined diseases (chronic lymphocytic leukemia, multiple myeloma and acute myeloid leukemia), thus showing potential for plasma proteome investigation. Because only 3 plasma samples were investigated we have to emphasize that obtained results may not be used to generalize differences for the three investigated diseases. IAC with the use of a CIM $\alpha$ HSA column enables enrichment of less abundant plasma proteins, thus providing the tool to enhance the relative presence and/or influence of potential disease biomarkers. Enrichment of plasma proteins in flow-through fractions was verified with SDS-PAGE and analyzed with DSC. The obtained results suggest that combination of DSC and IAC could be introduced as a possible novel and non-invasive diagnostic tool, although further research in this field is required.

\section{Acknowledgements}

We acknowledge the financial support of the Slovenian Research Agency through Program Groups P1-0201, P4-0121 and P4-0369. We are also grateful to Iva Hafner Bratkovič for contributing important knowledge on making and staining SDS-PAGE gels. This work was partially supported by the European Commission FP7 projects Prot-HiSPRA (grant number 282506) and HTP-GlycoMet (grant number 324400).

\section{References}

1. R. Mayeux, Neurotherapeutics, 2004, 1, 182-188. http://dx.doi.org/10.1602/neurorx.1.2.182

2. N. C. Garbett, J. J. Miller, A. B. Jenson, J. B. Chaires, Biophys. J., 2008, 94, 1377-1383.

http://dx.doi.org/10.1529/biophysj.107.119453

3. P. Maurya, P. Meleady, P. Dowling, M. Clynes, Anticancer Res., 2007, 27, 1247-1256.

http://ar.iiarjournals.org/content/27/3A/1247.long

4. N. C. Garbett, M. L. Merchant, C. W. Helm, A. B. Jenson, J. B. Klein, J. B. Chaires, PLoS One, 2014, 9, e84710, 1-12. http://dx.doi.org/10.1371/journal.pone.0084710

5. T. Čerk Petrič, P. Brne, B. Gabor, L. Govednik, M. Barut, A. Štrancar, L. Zupančič Kralj, J. Pharm. Biomed. Anal., 2007, 
43, 243-249. http://dx.doi.org/10.1016/j.jpba.2006.06.019

6. C. Wu, J. Duan, T. Liu, R. D. Smith, W.-J. Qian, J. Chromatogr. B Analyt. Technol. Biomed. Life Sci., 2016, 1021, 57-68. http://dx.doi.org/10.1016/j.jchromb.2016.01.015

7. U. Černigoj, U. Vidic, B. Nemec, J. Gašperšič, J. Vidič, N. Lendero Krajnc, A. Štrancar, A. Podgornik, J. Chromatogr. A, 2016, 1464, 72-78. http://dx.doi.org/10.1016/j.chroma.2016.08.014

8. N. C. Garbett, C. S. Mekmaysy, C. W. Helm, A. B. Jenson, J. B. Chaires, Exp. Mol. Pathol. 2009, 86, 186-191. http://dx.doi.org/10.1016/j.yexmp.2008.12.001

9. C. M. Stoscheck, Methods in Enzymol., 1990, 182, 50-69. http://dx.doi.org/10.1016/0076-6879(90)82008-P

10. I. A. Tarasova, A. A. Lobas, U. Černigoj, E. M. Solovyeva, B. Mahlberg, M. V. Ivanov, T. Panić-Janković, Z. Nagy, M. L. Pridatchenko, A. Pungor, B. Nemec, U. Vidic, J. Gašperšič, N. Lendero Krajnc, J. Vidič, M. V. Gorshkov, G. Mitulović, Electrophoresis, 2016, 37, 2322-2327. http://dx.doi.org/10.1002/elps.201500489

11. U. K. Laemmli, Nature, 1970, 227, 680-685. http://dx.doi.org/10.1038/227680a0

12. M. Chevallet, S. Luche, T. Rabilloud, Nat. Protoc., 2006, 1, 1852-1858. http://dx.doi.org/10.1038/nprot.2006.288

13. C. M. Olsen, H.-T. Lee, L. A. Marky, J. Phys. Chem. B, 2009, 113, 2587-2595. http://dx.doi.org/10.1021/jp806853n

14. N. C. Garbett, M. L. Merchant, J. B. Chaires, J. B. Klein, Biochim. Biophys. Acta, 2013, 1830, 4675-4680.

http://dx.doi.org/10.1016/j.bbagen.2013.05.007
15. A. Michnik, Z. Drzazga, K. Michalik, A. Barczyk, I. Santura, E. Sozańska, W. Pierzchała, J. Therm. Anal. Calorim., 2010, 102, 57-60. http://dx.doi.org/10.1007/s10973-009-0602-6

16. L. Kikalishvili, M. Ramishvili, G. Nemsadze, T. Lezhava, P. Khorava, M. Gorgoshidze, M. Kiladze, J. Monaselidze, J. Therm. Anal. Calorim., 2015, 120, 501-505. http://dx.doi.org/10.1007/s10973-015-4426-2

17. S. Todinova, S. Krumova, L. Gartcheva, C. Robeerst, S. G. Taneva, Anal. Chem., 2011, 83, 7992-7998. http://dx.doi.org/10.1021/ac202055m

18. G. A. Picó, Int. J. Biol. Macromol., 1997, 20, 63-73. http://dx.doi.org/10.1016/S0141-8130(96)01153-1

19. A. Kumar Shaw, S. Kumar Pal, J. Photoch. Photobio. B., 2008, 90, 69-77. http://dx.doi.org/10.1016/j.jphotobiol.2007.11.003

20. D. F. Keren: Protein Electrophoresis in Clinical Diagnosis, Hodder Arnold, London, Great Britain, 2003, pp. 63-108 and 151-168.

http://www.aun.edu.eg/molecular_biology/Protein $\%$ 20workshop/\&\%20Protein\%20Ele ctrophoresis_clinical\% 20diagnosis.pdf

21. R. Thakur, A. Das, V. Sharma, C. Adhikari, K. S. Ghosh, A. Chakraborty, Phys. Chem. Chem. Phys., 2015, 17, 1693716946. http://dx.doi.org/10.1039/c4cp05734a

22. F. Barcelo, J. J. Cerda, A. Gutierrez, T. Jimenez-Marco, M. A. Duran, A. Novo, T. Ros, A. Sampol, J. Portugal, PLoS ONE, 2015, 10, 1-15.

http://dx.doi.org/10.1371/journal.pone.0120316

\section{Povzetek}

Diferenčna dinamična kalorimetrija (DSC) nam nudi svojevrsten vpogled v lastnosti proteoma krvne plazme. Termogrami krvne plazme bolnih posameznikov so specifični in se razlikujejo med seboj, kakor tudi od krvne plazme zdravih posameznikov. Z DSC smo izmerili termograme krvne plazme posameznikov s kronično limfatično levkemijo, plazmocitomom in akutno mieloično levkemijo ter jih med seboj primerjali. Da bi pridobili dodatne informacije o termično inducirani denaturaciji plazemskih proteinov, smo uporabili imunoafinitetno kromatografijo. S kromatografsko kolono z imobiliziranimi anti-HSA protitelesi smo izvedli imunoekstrakcijo HSA in s tem povišali delež manj pogostih proteinov v krvni plazmi. To nam je omogočilo snemanje termogramov frakcij z različno proteinsko sestavo in s tem boljše razumevanje interakcij med proteini, ki sestavljajo krvno plazmo. Učinkovitost odstranitve HSA in sestavo frakcionirane krvne plazme smo preverili z uporabo SDS-PAGE. 